\title{
良導絡と古典編 $(2)$
}

\section{中 谷 義 雄}

\section{五行説についての私見}

経絡様のものが存在するや否やについて論 争されているとき、五行説はそれ以上に神秘 的でもあり、又あまり信じられていないので 益々問題である。この五行説について私の今 までの実験や考察から私見を加えてみた。五 行説の発生の過程は一朝一夕に出来上ったも のではなく長年月の間に相勊関係が発見され、 ついで相生関係と云う様にだんだんと進歩発 展したものであり、昔の人達が世の中を構成 する要素は木火土金水であると考えて、その 木火土金水の関連性の中に相生相尅的な関係 を見出したものであると考えられる。易学的 なものにはふれないことにして、宇宙森羅万 象のすべては、この五行的な関係で支配され ているとし、気学と称せられて研究されてい る。こうした支配は人は小宇宙と考えられて いるので人類にも適応されると考えられ、人 体では経絡に五行的支配があるとされた。御 承知の如く木には肝、膽経。火性には心、小 腸、心包、三焦経。土性には脾、胃経。金性 には肺、大腸経。水性には腎、膀胱経。があ てられている。この様に配当された経絡間に 五行説的な相生、相勊関係があるとし、又各 経絡の井、栄、俞、経、合、とよばれる経穴 には陰経ではそれぞれ木、火、土、金、水、 の性質があり、陽経では配当するに金、水、 木、火、土、の性質があるとされている。ま たこの様な関係から、虚した経絡を実せしむ るにはその母を補し、実している経絡にはそ の子を浑すと云う様な治療原則が定められて いる。以上によって、何穴は何経を実せしむ る経穴であると云うことがわかる。これを補
穴とし、実を瀉する経穴を瀉穴とすると、補 穴、濜穴は一定の定まった位置（経穴）をも っているわけである。私の意見をのべるなら ば、井、栄、俞、経、合、が木、火、土、金、 水、或は金水、木、火、土、の性質をもって おり、補するにその母を補し、瀉するにその 子を瀉すと云う。この 2 つが真理であって、 その結果、補穴、瀉穴が定まったとは考えら れない。補穴、瀉穴が経験上知られていて、 これに五行的な関係をやや無理なところがあ ったが、当てはめたと考えるのが妥当である。 無理にあてはめたと云う理由は形式をととの える為、つまり（補するには、その母を補し、 㴼するにはその子を潟す）と云う法則にあう ようにする為に次の様な無理をしたと考えら れる。

1 ）井栄俞経合は末梢の経穴から順にある が、重要穴と称して、経穴を適当にとば している。

2 ）井栄俞経合は陰経ではそれぞれ木火土 金水の性質をもっているとされているが 良導絡ではそうした性質は認められなか った。それに陽経では井栄丞経合を金水 木火土をあて〉いる。

以上の 2 つから考えて先の法則を満足させ る為の細工であると云える。勿論この細工は 巧妙に出来ており又記憶の便利と云う点では すぐれている。がしかし、こうしたあてはめ 式便利主義的な説明を土台にして次々と考察 を加えることは出来ない。即ち科学的でない と云うことになる。

次に良導絡の面から五行説を考察してみよ う。 
(1) 代表測定点で電流量を測定することは、 その良導絡の興奮性を代表するものである。 それで、左代表測定点、12力処で実験用測 定器で通電抵抗を測定し、各良導絡の一つ ずつに施众刺激を加えてみた。そして（肝、 膽）（心、小腸、心包、三焦）(脾、胃） （肺、大腸）（腎、膀胱）の 5 つのグルー プに分けて、刺激によって特に強く反応し た方向をしらべてみると、古典の、所謂相 生、相赾の方向は刺激による反応の起りや すい方向であると云うことがわかった（五 伝導方向)。

(2) 左陽経の各経絡から一つずつ任意に経穴 を選んで、指圧を加えて圧痛を起させ。そ の他の経穴を指圧して、先の圧痛が消失す るや否やをしらべてみると、所謂相生の逆 方向に圧痛が移動することがわかった。相 赾の方向及びその逆の方には仲々移動しな かった。このことは所謂、相生、相赾関係 は刺激による反応の起りやすい方向であっ ても、性質が異るのではないかと思考され る。

(3) やはり 5 つのグループに分けて48例の統 計の結果からみると、

或グループの中に特に臓系良導絡の興奮性 の高い時は、古典の相勊の方向の腑系良導絡 の興奮性が低い場合が多い(この方向を抑制 線と名づけた)。又或グループの中に特に藏 系良導絡の興奮性が低い時は、古典の相生の 方向の腑系良導絡の興奮性が高い場合が多い (この方向を興奮線と名づけた)。良導絡に 古典相生、相勊に相当するものが存在する。

(4) 脈診部位六部定位の通電抵抗を測定し、 蔵系良導絡上の任意の良導点を刺激すると、 統計的には、特定の臓器の虚実をみるとさ れている脈診部位（六部定位の内の一つ） に最も強く反応を現わし、次で 2 位の反応 を示すものをしらべると、その方向は抑制 様（相起）の方向である、即ち（肺良導絡 上の孔最を刺激すると右寸口に最も反応し、 次は右関上に反応を起す。肺良導絡からみ れば脾良導絡は抑制線上にある)。

以上の 4 つから考察すると、古典に云う相
生相赾と云う傾向は良導絡にも存在すると云 うことになってくる。従って五行説と云うも のは全く荒唐無稽のものと云うより、むしろ、 そうした傾向があるとしなければならない。 しかし、五行説的なものが存在しなければ有 効な治療点が求められないと云うわけのもの でもない。五行説を否定しても立派に臨床的 には立ちゆくのである。つまり、古典で云え ば補穴、瀉穴、良導絡で云えば興奮点、抑制 点の理で立派に本治法が出来るわけである。 又各例が皆相生相勊的な関係におかれている ものではなく、統計的に、そうした関係にお かれてあるものが最も多いと云う、唯それだ けである。だから五行説に完全にしばられて いるものではないわけである。私はここで疑 問に思うのは、この様な程度の傾向しか有し ない五行説を、どうして人体惣てにあてはめ たかと云うことである。つまりこの様な経絡 の相関関係をどうして知ったか。1を聴いて 10を知るの想像を利かしたか。勿論肝膽を木 性。心、小腸を火性。脾、胃、を土性。と云 う様にして如何にあてはめたかという様なこ とを特に不審に思う。又もう一つ、火性の中 には心、小腸経の外に心包、三焦経がある。 心包、三焦を加えると 6 つのグループが出来 上るわけであるが、木火土金水と 5 つに分け、 心包、三焦経を如何なる理由で火性としたか。 但し、これは良導絡の面から研究してみると、 なる程と思われるデーターが出ている。それ は腎、膀胱良導絡を刺激すると、その反応は 肝膽、心、小腸、心包、三焦良導絡に起りや すい。そして、その内、心包、三焦良導絡の 反応は最も弱い。次に肝膽良導絡を刺激する と、その反応は心、小腸、心包、三焦、脾、 胃良導絡に起りやすい。そして心包、三焦良 導絡の反応は最も弱い。次に心、小腸、良導 絡及び心包、三焦良導絡を刺激すると、その 反応は脾、胃、及び肺、大腸良導絡に起りや すい。処が、心包、三焦良導絡を刺激すると、 心、小腸良導絡を刺激した時より強く作用す る。それで心、小腸良導絡（代表測定点）は 測定に適し、心包、三焦良導絡は刺激に適す るのではないかと考えられると同時に、そう 
した違いはあっても、刺激を受ける反応の方 向及び与える方向が同じであるので古典で心、 小腸、三焦経心包経を火性とよんだと云う理 由がうなずかれるわけである。

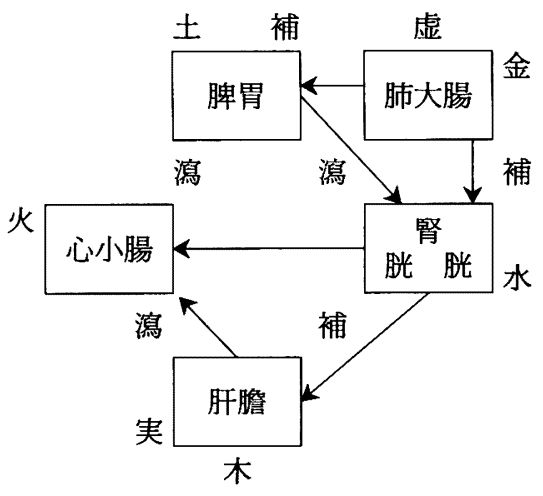

最後に難経の七十五難に治療変則が述べら れている。これについては色々と説がある様 であるが、これにも私見を加えてみたい。

七十五難の変則と云うのは、或るグループ に虚があり、その相勊の方向に実がある場合 であって、この様な時には、今までの治療原 則である「虚にはその母を補し、実にはその 子を瀉す」があてはまらないと云うのである。 結論を先にのべると、この様な型の場合には 「実するものはその子を鴧し、虚はその子を 補す」と云うのである。虚の場合だけが変つ ている、母を補すが、子を補すに変っている のである。どの様な意味あいで、こうなった かと云う説明が問題である古典の説明よりは なれて、良導絡の面からの知恵をかりて説明 をすると、今仮りに肝膽実で肺、大腸の虚の 場合、これは七十五難の変則であるが、これ を原則的な治療を行ったと仮定すると次の様 になる。肝膽を瀉する為に火性を瀉す。次に 肺大腸を補する為に土性に補す。こると土性 が実となり、相赾の水性が虚してくる。水性 が虚してくると、（良導絡の場合には、興奮 性の低いグループの相生の方向に興奮性の高 いものがある場合が多い。その方向を興奮線 と名づけた。）木性が実してくる。木性が実 してくると、木が実で瀉そうとしているとき であるから具合が悪い。故に、七十五難型の 場合虚の母を補すことはいけないと云う説明
になる。本間先生がこれによく似た説明をし ておられた様に記憶しているが少し説明が著 者のとはちがっているはずである。以上はあ くまで後からつけた説明であって、古典的便 利主義にもとづく説明との難はまぬがれない。 虚の子を補すと水性は実してくる。実の相起 は抑制されて瀉せられ、先の木の子火性を瀉 すと一致してくる。七十五難の理くつはなる ほどわかった。しかし、実際上この様な型で 原則的な治療を施しても効果のないものであ ろうか、私の少い臨床例では、無理にこの型 に原則的治療を加えたが、本治法だけで、か なりの効果が現われた。その直後、変則の治 療点だけを加えると、今あがった効果より、 より以上に症状の軽快をみた。通電抵抗のバ ランスより、変則が事実必要のものであろう か、古典いじりから生じたものであるかを研 究してみたい。もし、変則が必要であること がわかれば、すべてのものを無理に五行説に あてはめたものではなく、そうした傾向があ ったればこそ、あてはめたもので、臨床経験 上、五行説は正しく、その不適な型を認め七 十五難の変則を作り、例外としたと云うこと になる。例外があると云うことはかえって、 五行説が正しい傾向であると云えるのではな かろうか、これらを断じるには先づ七十五難 の変則が必要のものであると云うことを証明 しなくてはならない。

良導絡は左右 24 条あり、それぞれの左右良 導絡間にはシーソー関係があり、又表裏良導 絡（臓系、腑系良導絡）にもシーソー関係が あるのでどうしても 6 つのグループに分ける 必要が生じてくる。そして、心包と三焦良導 絡と心、小腸良導絡のグループは同じ様な傾 向がみられるので一応同じグループの仲間に しておかねばならない。前者は刺激に適し、 後者は測定に適するので、測定は心包、三焦 良導絡をのぞいた20代表測定点で測定してい るが、将来の発展の為にも心包、三焦良導絡 でも測定しておいた方が良いと思う。(現在 は心包、三焦良導絡で測定している)

結論として、良導絡の研究からみると、五 行説的傾向はある。但し絶対的なものではな 
い。すべて、経絡、五行説を真向から否定す ることによって科学的であると考えておられ る方がおられるが、否定するには否定する根 拠が必要である。私は五行説が正しいと断定 するには今日また其証左十分だとは思ってい ない。そうした傾向が存在する様だと云って いるのである。反之、否定するとなると、其 の否定証左の事実を示さねばならぬ。それは 今日の自分にはとても出来ない。反対の科学 的証拠が無くて反対をする、而かも公言する 科学者の如き虽を後に遺すことを怖れるから である。

\section{科学的に観た古典五行説}

\section{一特に井栄渝経合についての見解一}

古典五行説では「五行中に五行あり」と云 われ、世の中には完全に純粋のものはないこ とを想はしめる。皆他の物の性質を含んでい るというのである。即ち木は観念として純粋 であるが、実際には木の中には水あり、金あ りと云う様に木性の肝経の中にも経穴によっ て、他の経絡の性質をもっているものがある とのべている(1)。良導絡は経絡の証明ではな いが、両絡には偶々相似の処のある事は既述 の通りであるが、古典が探り入れた思想の中 にも類似の点を発見し得る様である。即ちど の良導点を刺激しても、刺激した良導絡のみ 反応して、他の良導絡には全く反応がないと 云う様な例はなかった(2)。処で古典では各経 絡上に木火土金水を以て意味される性質をも ったものがあり、それを井栄俞経合と云った 言葉で表現している。

経絡 $\left\{\begin{array}{l}\text { 陰経では }\left\{\begin{array}{l}\text { 井 } \rightarrow \text { 木性 } \\ \text { 栄 } \rightarrow \text { 火性 } \\ \text { 俞 } \rightarrow \text { 土性 } \\ \text { 経 } \rightarrow \text { 金性 } \\ \text { 合 } \rightarrow \text { 水性 }\end{array}\right. \\ \text { 陽経では }\left\{\begin{array}{l}\text { 井 } \rightarrow \text { 金性 } \\ \text { 栄 } \rightarrow \text { 水性 } \\ \text { 俞 } \rightarrow \text { 木性 } \\ \text { 経 } \rightarrow \text { 火性 } \\ \text { 合 } \rightarrow 土 \text { 土性 }\end{array}\right.\end{array}\right.$
そして一般には例えば肺経の井穴を刺激す ると木性即ち肝膽経の方に作用するという様 に考えている。又肺経を主として考えるとき、 肺経上の俞穴（土性）を刺激すると肺経が補 せられ、肺経上の合穴（水性）を刺激すると 肺経が鴧せられると云っている。それを次の 様な言葉で云いあらわしている。即ち補する にはその母を補い、瀉するにはその子を瀉す、 これが古典に於ける経穴による補瀉の原理で ある。処でこの原理たる命題は果して真理を 表現して居るか否か。笹川(7)は古典医法の基 礎たる Sache とその帰納的命題を作る処迄 は合法性を認め、近代化学的の性格を認める が、それから後のWiSSenに科学の無かっ た国柄らしい論理の飛躍や不合理あることを 指摘して居るが、古典全体を通じての哲理は 却々容易に之を否定し去るべき根拠は発見し 難かるべしと警戒して居る。著者も亦近代医 学的診療の実際に当って如斯理を考へしめら れる事実に遭過するので、之に則して聯かの 見解を開陳し度い。この考察は良導絡の研究 成果から古典を批判し考察したものであるか ら、理論的検討 theoretische Verifikation には無理の無かるべきを信ずるのであるが、 前述の如く批判考察の対象に陰陽五行的要素 を多分に含む処から石川日出鶴丸(8)の所説の 如く循環論的矛盾論のそしりをまぬがれない 処があるやも知れない。

(1) 良導絡は経絡とは非常に多くの面で相似 的な性質をもっている形態(2)、五伝導方向 (3)、相生相赾(4)、興奮点、抑制点(3)、六部 定位(5)の関係等。

(2) しかるに古典に云うが如き井栄俞経合の 性質は良導絡に於てはみられなかった(5)。

(3) それにもか〉わらず古典の補点と瀉点が 興奮点と抑制点と云う形で相似的である(3)。 以上の三つを土台にして考察してみるに、

(2)の古典の理論と良導絡の実験事実とが一 致しないで、しかもその結論とも云うべき補 点、䵘点と興奮点と抑制点が一致すると云う ことは、結論の経絡上に於て、その経絡の補 点と淊点とを経験的に先づ知っていてそれに 五行的な理論を後で強いてつけようとしてつ 
けたものと考え度い。而かもその理論は何ら 根拠のない巧妙なあてはめ式のものであった と思われる。緒言所述にもある通り、この辺 が笹川の指摘する如く遍妥普当律形成に無理 を敢行した処であるまいか、隨つて井、栄、 俞、経、合は末梢から井、栄、俞、経、合と 云う順序にはあるが、経穴の順番通りになっ ていない。そして陰経と陽経では同じ井でも 陰経では木性、陽経では金性と云う様な多少 の無理か出来ている。条経絡の補点、瀉点に ついてもう少し考察を加えてみると巧妙なる あてはめであったことが窥知出来る。それに しも却々念の入ったあてはめではある。

○陰経の補点について考察するに、火性心 経の補点は井穴で末梢から一つ目の経穴にあ たる。土性脾経の補点は栄穴で末梢から二つ 目の経穴、金性肺経の補点は俞穴で末梢から 三つ目の経穴、水性腎経の補点は末梢から七 番目の経穴、木性肝経の補点は合谷で末梢か ら九番目の経穴であると云う様に、火性より 右まわりにだんだんと末梢より遠ざかってい る。

\section{○踰経の㴧点について}

次に鴧点について考察を加えてみるに、 水性腎経の瀉点は井穴で一番目の経穴、 木性肝経の鴧点は栄穴で二番目の経穴、 火性心経の潟点は俞穴で五番目の経穴、 金性肺経の瀉点は合穴で八番目の経穴、 と云う様に水性より右まわりにだんだんとそ の鴧点の経穴が末梢より遠ざかっている。

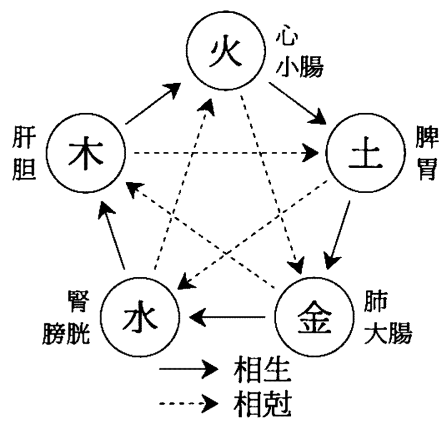

これを表にするとわかりやすい。

この表は補点 12379 を 3 と $7 、 7$ と 9 の間の補鴧点との関係のない経穴をとばして 12345 とする。滨点 12358 を、3 と

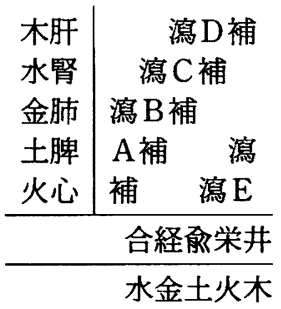

$5 、 5$ と 8 の間の補鴧点と関係のない経穴を とばして1 123445 と云う様に現わすと表の 様に補と瀉とがうまく一つ空をおいて並ぶ、 これは一つの法則性をもっている様に考えら れることであるから、これを利用することに よって心経の補点と瀉点の関係をおほえやす くすることが出来るわけである。空の A B C DEを中心にして考えると一つ左まわりには 補となり、一つ右まわりは鴧点となる。Aを 心経で考えると火性より一つ左まわりは木性 であり、それを井穴と名づける。その経穴は 補点であるから、これを古典の言葉をかりて 云うならば、その母を補いと云うことになり、 一つ右まわりは土性であり、それを俞穴と名 づけると、経穴は淊点であるから、その子を 瀉すと云うことになる。

この様にして補点と潟点とを先づ経験で知 ってこれを色々の面から検討して記憶の便と か、或は一つの体系を作る為に考えに考えて、 この様なことを発見したのではないだろうか。

つまり事実から出発して、その後にうまく 理窟をつけたものと思われる。但し近代科学 に於ける学問の論理化の様に事実から帰納し て当り得られる処の普遍妥当律とも称し難い 命題である。又恐らく理論から出発して事実 をつかんだものなどとも到底考えられない。

\begin{tabular}{|c|c|}
\hline $\begin{array}{l}\text { 木 膽 } \\
\text { 水膀胱 }\end{array}$ & $\begin{array}{l}\text { 潟 } \mathrm{E} \text { 補 } \\
\text { 潟 D補 }\end{array}$ \\
\hline 金大腸 & 補 瀉 C \\
\hline 土 胃 & B補瀉 \\
\hline 火小腸 & 潟 A 補 \\
\hline & 合経俞栄井 \\
\hline
\end{tabular}

陽経の場合を考えてみるに、

次の様な表が出来た。小腸経を中心にして 考えると、Aの一つ現まわりは木性で補点と 
なり、右まわりは土性で瀉点となっている。 前と同様、補するにその母を補い、潟するに はその子を㴼すと云うことには変りない。

然し、前と異るのは、末梢から井栄俞経合 と名づける、陰経では木火土金水であるが陽 経では金水木火土になってくる。こ〉が問題 であって、結論からわり出さなくてはこの陽 経の金水木火土が仲々出てこないはずである。 そして、その他の例えば、陰経に於ける心経 の合経栄、脾経の合俞井、肺経の経栄井等が はたして、その表に現われた木火土金水の性 質を示すかどうかが問題となってくる。通電 抵抗からは、その様な性質があるとは思えな 认。

積極的に事実を以て否定することは出来な いにしても、うたがいはもたれる。

以上の様な推理考察を加えるには未だ充分 な事実を提供し得ない感無きにしもあらずで はあるが、現在に於ける著者の立場を以てす る世界観から考察を加えてみれば如斯主張し 度い。又五昧についても黄色の薬品は脾胃に よいとされているが、それはその当時の薬草 である。黄蓮、黄柏、黄芩、と云った黄色の 薬品が脾胃に良いから云ったもので、現代の アクリナミン、リバノールが脾胃に良いとは 考えられない。隨つて古典を修正しないで現 代にあてはめることは難しいのみならず不当 でもある。しかしその当時としては大局をつ かんでいる処があり、笹川の警告する如くど こか哲理を含む処が多分にある故を以て全く 無価値なものとし荒唐無稽のものとして一概 に排し去るのも妥当でなく、理論の展開に警 戒を払いつ>研究する必要があるものであろ う。之要、前述の如く相当無理な非科学的な 推理をもまじえて出来ていると思われる節が 発見されるので、古典全部が真理を把握し、 その記載が真理表現の命題だと妄信し得ない であろう。

井栄俞経合に対する理論的検討でも窥知し 得る如く古典五行説は全く荒唐無稭と断ずる ことは出来ない様であるが、無批判に之を肯 定することも危険である。命題の基盤たる㷌 納の根拠的事実は、少くとも古典を鍼炎術と

共に主として経験を土台として組立てた Sache であるから、科学的のものであるが、 その理論殊にその展開の仕方は科学的でない 場合が普通である。科学の無かった東洋には 優れた真理をもったものでもそれが後世に伝 えられるにつれ歪んで来たと思われるものが 多い。

\section{経絡と良導絡の対照}

良導絡と経絡とは同じものではないと云う ことはこれ迄常々云ってきた処であるが、鍼 负師の古典を知っている方が良導絡の研究を する場合、やはり比較対照して、古典のこれ が良導絡ではこれにあてはまると云ったよう なことがわかれば、良導絡の道に入りやすい わけで、入ってしまえば良導絡を学問的に少 くとも科学的に理解してもらわねばならない のであるが、便宜上と云う言葉をつかって、 比較対照してみることにする。

経 穴 $\rightarrow$ 良導点

経 絡 $\rightarrow$ 良導絡

肺 経 $\rightarrow \mathrm{H}_{1}$ 良導絡 心包経 $\rightarrow \mathrm{H}_{2}$ 良導絡 心 $\quad$ 経 $\rightarrow \mathrm{H}_{3}$ 良導絡 小腸経 $\rightarrow \mathrm{H}_{4}$ 良導絡

三焦経 $\rightarrow H_{5}$ 良導絡 大腸経 $\rightarrow \mathrm{H}_{6}$ 良導絡 脾 経 $\rightarrow F_{1}$ 良導絡 肝 経 $\rightarrow F_{2}$ 良導絡

腎 $\quad$ 経 $\rightarrow F_{3}$ 良導絡 膀胱経 $\rightarrow F_{4}$ 良導絡 膽 経 $\rightarrow F_{5}$ 良導絡

胃 経 $\rightarrow F_{6}$ 良導絡
任 脉

$\rightarrow \mathrm{V} \cdot \mathrm{M}$ 前正中良導絡 督 脉

$\rightarrow \mathrm{H} \cdot \mathrm{M}$ 後正中良導絡 経穴名は、良導絡に於 ては、その良導点の所 属する良導絡の末梢か ら一連番号をつけ肺良 導絡末梢から 5 番目で あれば $\mathrm{H}_{1} 5$ としてある。 原 穴 $\rightarrow$ 代表測定点 五 行 $\rightarrow$ 五伝導方向 相 生 $\rightarrow$ 興奮線 相 起 $\rightarrow$ 抑制線 補 穴 $\rightarrow$ 興奮点 䳆 穴 $\rightarrow$ 抑制点 虚 $\rightarrow$ 電流量が生理的よ り少い（代表測定点） 実 $\rightarrow$ 電流量が生理的よ り多い（代表測定点） 